\title{
Icelandic modal verbs revisited
}

\author{
Höskuldur Thráinsson \\ University of Iceland
}

\begin{abstract}
The syntactic differences between epistemic modals and root modals have often been described in terms of raising vs. control: Epistemic modal verbs are then said to be like raising verbs in not assigning a thematic role to their subject and hence allowing raising of embedded arguments to their subject position, whereas root modals are like control verbs, assigning a thematic role to their subject and hence disallowing raising of embedded arguments. This is, for instance, the analysis proposed for Icelandic modals by Thráinsson \& Vikner (1995). In this paper it is argued that the control analysis of root modals is appropriate for the so-called subject-oriented readings of root modals but probably not for non-subject-oriented readings.
\end{abstract}

\section{Introduction}

In discussions of modal verbs, it is standardly assumed that they (or their interpretations) fall into two main classes, epistemic and root. ${ }^{1}$ The term root is not very transparent in itself. To make things more difficult, the descriptions of these classes and their semantic characteristics vary somewhat in the literature. One of the reasons is that the scholars writing the descriptions have different interests. Some of them are mainly interested in coming up with general semantic or philosophical definitions of the concepts "epistemic" and "root" (or "deontic" and "dynamic", which are often taken to be subclasses of "root" in this context, as will be described below), giving explanatory examples from various languages along the way to illustrate their points. Others concentrate on the linguistic

1 Many thanks to the editors and an anonymous reviewer for useful comments and important corrections.

Ken Ramshøj Christensen, Henrik Jørgensen \& Johanna L. Wood (eds.). 2019.

The Sign of the V-Papers in Honour of Sten Vikner.

Dept. of English, School of Communication \& Culture, Aarhus University, pp. 619-642, doi:10.7146/aul.348.117. (C) The author(s). 
manifestations certain aspects of "modality" in a particular language, e.g. the possible or most common interpretations of modal verbs found in that language. Since there is crosslinguistic variation in this area (see e.g. Palmer 1986), it is not surprising that the descriptions of epistemic modals and root modals will vary in detail. This can be illustrated with a couple of examples from the literature.

As an example of a relatively short description of the differences between epistemic modals and root modals we can take the following (Wurmbrand 1999: 599):

epistemic modal statements express necessity or possibility relative to some state of knowledge or beliefs; root (sometimes also referred to as deontic) modal statements express forces like permission, obligation etc. relative to some normative system

In a foonote, Wurmbrand (1999: 599) states that these "two classes of interpretations involve a number of subclasses that will not be distinguished here since it will not affect the arguments made in the paper", referring to Palmer (1986) and Brennan (1993) for details. Brennan in turn (1993: 7-9) builds to some extent on Jackendoff's (1972) classification. The following examples are based on Brennan (1993: 8), and they are meant to illustrate the difference between epistemic and root readings (the illustrative paraphrases are mine and $\mathrm{E}$ stands for epistemic, $\mathrm{R}$ for root):

(1) An aide de camp may read the classified reports.

a. It is possible that an aide de camp will read ...

E: possibility

b. An aide de camp has the permission to read ...

$\mathrm{R}$ : permission

(2) A student must ride this horse.

a. It is necessary that some student rides ... E: necessity

b. There is a student who has the obligation to ride ... R: obligation

(3) He can't swim after running.

a. It is not possible that he swims ... E: possibility

b. He does not have the ability to swim ... R: ability

c. He does not have the permission to swim ... $\quad$ R: permission

Many studies of modal verbs offer a more detailed classification of modal interpretations than those illustrated above. The syntactic 
characteristics of some of these are described in an overview by Barbiers \& van Dooren (2017) of previous research on modal verbs in various languages. Their paper includes the following descriptions of epistemic and root interpretations of modals (2017: 1-2, 27 fn. 2; see also Barbiers 2002: 1$):^{2}$

epistemic interpretations are a class of interpretations involving a speaker-oriented or, in the case of embedded clauses, matrix-subjectoriented qualification or modification of the truth of a proposition, while root interpretations involve the will, ability, permission, or obligation to perform some action or bring about some state of affairs.

There are two distinct uses of the term "root modality" in the literature: as equivalent to "deontic modality" or as including both deontic and dynamic modality. Deontic modality is about how the world ought to be, while dynamic modality is about a subject's internal capability or willingness to perform some action.

Modal verbs that can have deontic root readings would then include English may (permission) and must (obligation) whereas can (ability) and want (volition) would have a dynamic root reading.

Deontic modality is often divided into two subclasses, depending on the relationship between the modal verb and the subject. This can be illustrated by the following two examples from Norwegian:

(4) Norwegian (Eide 2005: 43, 48)

a. Jon bør være på kontoret.

Jon should be.INF on office-the

'Jon should be in his office.'

$$
\text { [ = Jon has the obligation to be ...] }
$$

b. Skildpadden bør være i badekaret.

turtle-the should be.INF in bathtub-the

'The turtle should stay in the bathtub.'

[ = that's the way it ought to be, $\neq$ the turtle has the obligation ...]

2 Page references to the paper by Barbiers \& van Dooren are to the pdf-version of it available on the internet. 
In (4a) it is stated that the subject, Jon, ought to do something, in (4b) it is said that a certain state or event ought to be or occur. Distinctions of this kind are typically described in terms of subject orientation. The reading in (4a) is then subject-oriented (it is about the subject's obligation) whereas the reading in ( $4 b)$ is non-subject-oriented (it is NOT about the subject's obligation).$^{3}$

Since dynamic root readings are typically about the "subject's internal capability or willingness to perform some action", they will normally be subject-oriented in the sense just described. Eide maintains, on the other hand (2005: 50), that in examples like the following the Norwegian modal ville 'will, want' has an "impersonal" dynamic volition reading:

\section{Norwegian}

a. Han arbeider hardt, men det vil bare ikke he works hard but it will simply not lykkes for ham succeed.INF for him 'He works hard, but he simply won't succeed.'

b. Det ville ikke slutte å regne denne dagen. it would not stop.INF to rain that day-the 'It just wouldn't stop raining that day.'

Example (5a) has an expletive subject and (5b) a weather-it, both being non-argumental, so no subject orientation is possible.

Having gone through the properties of Norwegian modal verbs, Eide ends up with the following classification of their possible readings and their relation to transitivity of the modal verb (adapted from Eide 2005: 52 and 174 with some modifications): ${ }^{4}$

3 Borrowing terms from Barbiers (1995), Eide (2005: 48) refers to the former sense as directed deontic reading, the latter as non-directed deontic. I will use the more common terms subject-oriented and non-subject-oriented here (a distinction that Eide reserves for the classification of different dynamic root readings, as described presently).

4 Eide actually uses the terms root vs. non-root as labels for the basic distinctions of modal readings rather than the more common root vs. epistemic. The reason is that she wants to be able to subclassify non-root readings into "epistemic proper", metaphysical and evidential (Eide 2005: 82). I will, however, continue to use epistemic as a cover term for these three readings, except when a more finely grained classification is needed. 


\begin{tabular}{|l|l|l|l|}
\hline $\begin{array}{l}\text { basic } \\
\text { type }\end{array}$ & $\begin{array}{l}\text { sub- } \\
\text { classification }\end{array}$ & $\begin{array}{l}\text { orientation and } \\
\text { transitivity }\end{array}$ & examples \\
\hline \multirow{3}{*}{ root } & \multirow{2}{*}{ dynamic } & $\begin{array}{l}\text { subject-oriented } \\
\text { dyadic }\end{array}$ & $\begin{array}{l}\text { ville 'want to' (volition), } \\
\text { kunne 'can, know' (ability) }\end{array}$ \\
\cline { 3 - 4 } & $\begin{array}{l}\text { non-subject-oriented } \\
\text { monadic }\end{array}$ & $\begin{array}{l}\text { ville 'will' (strong tendency) } \\
\text { kunne 'can' (weak tendency) }\end{array}$ \\
\cline { 3 - 4 } & \multirow{2}{*}{ deontic } & $\begin{array}{l}\text { subject-oriented } \\
\text { dyadic }\end{array}$ & $\begin{array}{l}\text { burde 'should, must' } \\
\text { (subject's obligation) }\end{array}$ \\
\cline { 3 - 4 } & $\begin{array}{l}\text { non-subject-oriented } \\
\text { monadic }\end{array}$ & $\begin{array}{l}\text { burde 'must, should' } \\
\text { (the way it should be) }\end{array}$ \\
\hline \multirow{2}{*}{ epistemic } & $\begin{array}{l}\text { non-subject-oriented } \\
\text { monadic }\end{array}$ & $\begin{array}{l}\text { burde 'must' } \\
\text { (necessity) }\end{array}$ \\
\hline
\end{tabular}

Table 1: Eide's classification of the readings available for Norwegian modals.

While the distinction between subject-oriented root readings and epistemic readings is very clear, the distinction between non-subjectoriented root readings and epistemic readings is often less clear. Consider the following Norwegian examples:

(6) Norwegian (Eide 2005: 51-52)

a. Dette vil garantert bli et problem for this will certainly become.INF a problem for

salgsavdelingen.

sales-department-the

'This will certainly be a problem for the sales department.'

b. Dette vil vanligvis bli et problem for this will usually become.INF a problem for

salgsavdelingen.

sales-department-the

'This will usually be a problem for the sales department.'

Eide maintains that (6a) has an epistemic (in her terms the subclass metaphysical) reading, being a prediction about the future due to the adverb garantert 'certainly, definitely', "a non-root reading, a speaker's commitment to the truth of a future situation". (6b), on the other hand, has a "root reading; it is a statement about recurring states of affairs in the world". 
The Icelandic modal vilja 'will, want' does not have the simple future reading that English will has (and to some extent also the cognate Norwegian ville). Statements about the future are typically made with the simple present tense as in (7), where future reference is made clear by the temporal adverbial á morgun 'tomorrow' (see e.g. Thráinsson 2007: 15-16):
Icelandic
раð rignir
örugglega á morgun.
it rains.PRS definitely
tomorrow
'It will definitely rain tomorrow.'

With this in mind, consider the following pair of examples:

\section{Icelandic}

a. Раð vill örugglega rigna af og til á morgun. it will definitely rain.INF off and on tomorrow 'It will probably tend to rain off and on tomorrow.'

$\begin{array}{llllll}\text { b. Раð vill oft } & \text { rigna } & \text { á } 17 . & \text { júní. } \\ \text { it } & \text { will often } & \text { rain.inf } & \text { on } 17 \text { th } & \text { June }\end{array}$ 'It often tends to rain on June 17.' ${ }^{5}$

Here (8a) is clearly "a prediction about the future" and based on that it should be "a non-root reading, a speaker's commitment to the truth of a future situation" according to Eide's argumentation above. But as indicated in the idiomatic translation, it has a "tendency reading", which according to Eide's classification illustrated in Table 1 should be a root reading ("strong tendency"). ${ }^{6}$ This shows that the distinction between root and epistemic readings is not always straightforward. This will be discussed in more detail in the following sections.

5 Iceland became a republic on June 17 1944; hence June 17 it is an important day (National Holiday) in Iceland. Rain is not particularly welcomed that day.

6 The addition af og til 'off and on' makes it easier to get the tendency reading. Eide reports (2005: 85) that a reviewer of her book claims that for "many Icelandic speakers" the verb vilja 'will, want' can only have a subject-oriented 'volition' reading. But she gives some examples (from Halldór Ármann Sigurðsson, p.c.) that can only have the 'tendency' reading. They are all completely natural for me. In a quick search in the Icelandic treebank IcePaHC (Rögnvaldsson et al. 2012) I found a similar example from 1628 (pað vill kosta nokkuð аð reisa i peim löndum 'it tends to cost a bit to travel in those countries') and the Icelandic database Tímarit.is, which has materials from Icelandic journals and newspapers, has a number of examples of vilja in this 'tendency' reading from various times, including this one from 1893: Mig vill gigt og preyta pjá 'Rheumatism tends to make me suffer'. But there is clearly some inter-speaker variation here. 
In section 2, I will discuss the classification of modal readings presented by Thráinsson \& Vikner (1995, henceforth T\&V) and show that they failed to distinguish clearly between subject-oriented and non-subject-oriented root modals. ${ }^{7}$ In section 3, I will review some characteristics of typical control constructions, comment on their properties with respect to theta roles and case marking and briefly compare them to subject-oriented root modals. In section 4, I argue that most of the criticism that has been levelled against T\&V's analysis of root modals only holds for the non-subjectoriented ones. I will further argue that a raising analysis of root modals in general is not viable, contrary to suggestions made by Wurmbrand (1999), Eide (2005), Barbiers \& van Dooren (2017) and others. Section 5 contains a few concluding remarks.

\section{2. $T \& V$ 's classification of modal readings}

To clarify what they mean by "epistemic" and "root" T\&V give a schematic representation including Icelandic, Danish and English modals. Their classification can be reproduced as in Table $2:^{8}$

\begin{tabular}{|c|c|c|c|c|c|c|c|}
\hline \multicolumn{3}{|c|}{ epistemic } & \multicolumn{5}{c|}{ root } \\
\cline { 5 - 8 } possibility & necessity & probability & report & obligation & permission & ability & volition \\
\hline kunna & hljóta & munu & munu & verða & mega & kunna & vilja \\
kunne & måtte & burde & skulle & skulle & måtte & kunne & ville \\
can & must & will & $?$ & must & may & can & will \\
\hline
\end{tabular}

Table 2: T\&V's classification of modal verbs in Icelandic, Danish and English.

7 T\&V mainly discuss Icelandic and Danish modal verbs. They argue that Icelandic epistemic modal verbs are like raising verbs in not assigning a thematic role to their subject and hence allowing raising of embedded arguments to their subject position, whereas Icelandic root modals are like control verbs, assigning a thematic role to their subject and hence disallowing raising of embedded arguments. $\mathrm{T} \& \mathrm{~V}$ propose a somewhat different analysis for Danish root modals to account for certain co-occurrence restrictions of Danish modal verbs, but I will limit my discussion for the most part to Icelandic modal verbs in this paper and arguments for and against T\&V's analysis of these. - Note that I am not trying to distance myself from my joint work with Sten Vikner by calling it "T\&V's analysis" and referring to the authors as they rather than we. I just found it convenient to refer to our work this way. The cooperation was pleasant and our paper is frequently cited. Thanks, Sten!

8 As T\&V acknowledge, their classification is to a large extent based on work by Davidsen-Nielsen (1990) and Coates (1983). Various other classifications can be found in the literature and the terminology tends to vary. Thus epistemic report is sometimes called hearsay evidentiality, for instance, as a reviewer points out. 
Table 2 is more detailed in some respects than Eide's Table 1 above, especially because it contains more subclasses of epistemic (or non-root) readings. More importantly, however, Table 2 does not distinguish between subject-oriented and non-subject-oriented readings whereas Table 1 does. This has important consequences as we shall now see.

As T\&V point out, Table 2 does not contain all Icelandic and Danish modal verbs. Hence they give a more complete list (1995: 54), plus example sentences in Danish and Icelandic illustrating the different readings as classified in Table 2. They first illustrate the epistemic readings and then the root readings. To give an idea of their classification, I will first present relatively uncontroversial Icelandic examples of epistemic readings, then Icelandic examples of straightforward root readings and finally turn to the more controversial examples and consider what we can learn from those.

\subsection{Epistemic readings}

To illustrate epistemic readings $\mathrm{T} \& \mathrm{~V}$ give the following Icelandic examples among others:

(9) Epistemic: possibility
a. Mig kann að vanta peninga. me.ACC can to lack.INF money
'I may need money.'
b. Раð getur rignt á morgun. it may rain.suP tomorrow
'It may rain tomorrow.'
c. Раð getur hafa rignt í nótt. ${ }^{9}$ it may have.INF rained in night 'It may have rained last night.'

(10) Epistemic: necessity

$\begin{array}{llll}\text { Рað hlýtur að hafa rignt í nótt. } \\ \text { it } & \text { must to have.INF } & \text { rained in night }\end{array}$

'It must have rained last night.'

9 Normally the modal verb geta 'may, can' takes the supine form of the following verb, cf. (9b) and (14b) below. But when it precedes the auxiliary hafa 'have' it selects the infinitival form, as modals typically do. 
(11) Epistemic: probability

a. Haraldi mun vera kalt.

Harold.DAT will be.INF cold

'Harold is probably cold.'

b. Honum atti að líka vel í Stuttgart. him.DAT ought.PST.SBJV to like.INF well in Stuttgart

'He should be happy in Stuttgart.' [= it is likely that he will be]

c. Раð æatlar að snjóa mikið í vetur.

it intends to snow.INF much in winter

'It looks like it will snow a lot this winter.'
d. Pað skal hafa
rignt í nótt. ${ }^{10}$
there shall have.INF
rained in night
'I'm (pretty) sure that it rained last night.'

\section{(12) Epistemic: report \\ Sten mun vera Dani. ${ }^{11}$ \\ Sten will be.INF Dane \\ 'Sten is reportedly Danish.'}

As the reader will have noticed, most of the examples illustrating epistemic readings (i.e. those in (9)-(11)) either have a weather-it subject or a non-nominative subject. This has the effect of making the examples unambiguosly epistemic in sense and ruling out the potential root readings of the verbs. $\mathrm{T} \& \mathrm{~V}$ account for this by adopting the (commonly accepted) analysis of epistemic modals as raising verbs: Like raising verbs, epistemic modals do not assign a thematic role to their subject and hence an argument

${ }^{10}$ In T\&V's paper the verb skulu in a similar example is written with capital letters to indicate special stress and they point out that the meaning is then very similar to that of hljóta in examples like (10) (T\&V 1995: 84-85, fn. 8). Dialectally (South-Eastern Iceland) it is also possible to find epistemic skulu in a 'reportive' sense, a reading also available for the Danish cognate skulle (cf. Det skal have varet besluttet 'It is said to have been resolved').

11 The verb kveða 'say' can be used in the reportive sense 'is said to'. Then it shows up in the past tense form (sg. kvað, pl. kváðu) although it has a present tense meaning: Рað kvað vera fallegt $i$ Kina 'It is said to be beautiful in China', Pau $\boldsymbol{k} v a ́ d u$ vera rík 'They are said to be rich'. In colloquial speech it is sometimes reduced to $k u$, which then does not show any subject agreement: Hún/Lau ku vera rik 'She is/They are said to be rich.' 
of the embedded infinitival verb can be raised into the subject position of the epistemic modal. Thus an epistemic modal can have a weather-it subject licensed by the embedded infinitival complement (as in $(9 \mathrm{~b}, \mathrm{c})$, $(10),(11 \mathrm{c}, \mathrm{d}))$ or a non-nominative subject selected by the embedded infinitival verb (as in $(9 a),(11 a, b))$. To account for the fact that Icelandic modal examples like the ones in (9)-(11) do not have root readings, T\&V adopt the (once popular) account that root modals are control verbs and consequently raising of elements from the embedded infinitival complement is not possible. So when it is obvious that the subject of the modal verb must have been raised from the embedded infinitival complement, as in (9)-(11), the root reading is impossible.

Not all the examples $\mathrm{T} \& \mathrm{~V}$ give to illustrate epistemic readings are as clear cut as those just considered. Before turning to such examples let us have a look at some examples of root readings.

\subsection{Root readings}

$\mathrm{T} \& \mathrm{~V}$ give the following Icelandic examples to illustrate root readings: ${ }^{12}$

\section{(13) Root: deontic obligation}

a. Ég verð að fara á fundinn.

I must to go.INF on meeting-the

'I have to go to the meeting.'

b. Ég hlýt að mótmæla pessu.

I must to object.INF this

'I must object to this.' ${ }^{13}$

c. Við eigum að hegða okkur vel. we ought to behave.INF ourselves well 'We ought to behave.'

d. pú parft ekki að gera petta fyrir mig. you need not to do.INF this for me 'You need not do this for me.'

12 Some of the examples below have been slightly modified for reasons of clarity.

13 Although the modal verb hljóta has a deontic obligation sense in (13b) (this is something that a politician could say, for instance), it is probably more commonly found in a logical inference sense, as a reviewer points out, e.g. : Pað er ljós í íbúðinni svo að hann hlýtur að vera heima 'The lights are on in the apartment so he must be at home.' 
e. bú skalt ekki stela.

you shall not steal.INF

'Thou shalt not steal.' ${ }^{14}$

(14) Root: deontic permission

a. Hún má taka minn bíl.

she may take.INF my car

'She can take my car.' [= she is allowed to]

b. pú getur borðað eins mikiðog pú vilt.

you can eat.SUP as much as you want

'You can eat as much as you want.' [= you are allowed to]

(15) Root: dynamic ability

a. Hann kann ekki að synda.

he can not to swim.INF

'He cannot swim.' [= does not know how to ]

b. Hún getur ekki talað dönsku.

she can not speak.suP Danish

'She cannot speak Danish.' [= does not know how to ]

(16) Root: dynamic volition

a. Hún vill læa málvísindi. she wants study.INF linguistics

'She wants to study linguistics.'

b. Hann æatlar að læra sálfræði.

he intends to study.INF psychology

'He intends to study psychology.'

As the reader will have noticed, the sentences in (13)-(16) all exemplify subject-oriented root readings. As pointed out above, these are easily distinguishable from epistemic readings since the latter are never subject-

14 This example is intended as a quote from the Ten Commandments. Usually the "obligation" expressed by the modal verb skulu is weaker, more like a suggestion as in Pú skalt laera málvísindi 'You should study linguistics'. With a first person subject it can also be an offer or a promise, as in Ég skal koma með rauðvín 'I'll bring red wine'. These variants could be further subclassified as different types of speech acts, but that is probably irrelevant here. 
oriented in the sense described above. But what about non-subject-oriented root modals? We will consider that question in the next subsection.

\subsection{Epistemic readings or non-subject-oriented root readings?}

Some examples that $\mathrm{T} \& \mathrm{~V}$ give as illustrations of epistemic readings are arguably instances of non-subject-oriented root readings. They include the following Icelandic ones:

\section{(17) Epistemic necessity or non-subject-oriented deontic root} reading (necessity)

a. Раð verður að rigna í kvöld.

it must to rain.INF to night

'It must (has to) rain tonight.'

[= otherwise we'll be in trouble]

b. Раð parf að rigna duglega.

it needs to rain.INF heavily

'It is necessary that it rains heavily.'

[= otherwise we'll be in trouble]

c. Mér má pá mistakast illa.

me.DAT must then fail.INF badly

'Then I would have to fail badly.'

[ = for that to happen, I would have to ...]

The first two examples contain a weather-it subject and the third one a non-nominative subject, as indicated by the gloss. While T\&V classify the reading of these examples as epistemic necessity, Eide (and presumably many others) would probably consider it to be non-subject-oriented (or non-directed) deontic reading (necessity or obligation).

Another potentially controversial example given by $\mathrm{T} \& \mathrm{~V}$ is the following:

(18) Epistemic possibility or non-subject-oriented dynamic root reading (tendency)

Hana vill oft vanta peninga.

her.ACC will often need.INF money

'She often tends to need (lack) money.' 
This is obviously similar to the examples in (6b) and (8b) above. As pointed out in the discussion of those, Eide maintains that this kind of reading is a root reading since it is not a prediction about the future but "a statement about recurring states of affairs in the world". But as described in the discussion around (8), the "tendency reading" is not restricted to statements that are appropriately modified by adverbs like oft 'frequently' but it can also be found in statements about the future. (19) is a case in point:

Hana vill áreiðanlega vanta peninga af og til her.ACC will certainly need.INF money off and on pegar hún er komin út. when she is come out

'She will certainly tend to to need (lack) money off and on once she is abroad.'

Although the tendency reading of vilja 'will, want' is probably most natural and common with adverbs like oft 'frequently', it is not ruled out with adverbs like áreiðanlega 'certainly, definitely' in statements about the future.

Whatever the proper classification of these examples may be, it is clear that the classification of modal readings offered by $T \& V$ was too simplistic. As a result, it left their analysis open to the criticism that will be discussed in section 4. But first it is necessary to review some properties of control verbs.

\section{Control verbs, theta marking, case marking and subject orientation}

Dyadic control verbs assign a thematic role to their subject, often that of an agent. The infinitival complement of such verbs is also typically agentive. Individual-level predicates are very odd in this context whereas stage-level predicates need not be (here \# means 'semantically odd'):
a. María reyndi að lesa bókina. Mary tried to read.INF book-the 'Mary tried to read the book.'

b. Sten reyndi að vera \#danskur/hjálpsamur. Sten tried to be.INF Danish/helpful

'Sten tried to be helpful.' ['tried to be Danish' sounds odd] 
Now consider the Icelandic non-nominative subjects. As has often been pointed out, they are never agents. Thus vanta 'need, lack, be missing' takes an accusative experiencer subject (dative for some speakers) and leiðast 'be bored' takes a dative experiencer subject. Both are unnatural in the infinitival complement of control verbs like reyna 'try' (I do not give idiomatic translations as the sentences are odd):
a. ?María reyndi
að vanta
ekki eina
í tíma. Mary
to lack.INF
not alone.ACC
in class

b. ?María reyndi að leiðast ekki í bókmenntatímunum.
Mary tried to be-bored.INF not in literature-classes-the

Interestingly, prepositional control verbs such as vonast til 'hope for', kviða fyrir 'be apprehensive about' and several others, typically taking experiencer subjects, are not as restrictive in this respect (see e.g. Thráinsson 2007: 419, 420n): ${ }^{15}$

a. María vonast til að vanta ekki eina í tíma. Mary hopes for to be-missing.INF not alone.ACC in class 'Mary hopes not to be missing alone from class.'

b. María kvíðir

$$
\text { fyrir }
$$

að leiðast

Mary is-apprehensive about

to be-bored.INF in

bókmenntatímunum.

literature-classes-the

'Mary is apprehensive about being bored in the literature classes.'

Now consider the subclassification of root modals into subject-oriented and non-subject-oriented ones. Given what has been described above, we would a priori expect subject-oriented root modals to behave more like control verbs than non-subject-oriented ones would, cf. the following quote from Wurmbrand (1999: 610):

The contexts in which (intuitively) the subject does appear to be in a thematic relation with the modal are modal constructions that

$\overline{15}$ As a reviewer points out, this is also true of some "non-prepositional" verbs like forðast 'avoid': María forðast að vanta eina í tíma 'Mary avoids to be missing alone from class.' 
involve what has been called a directed deontic interpretation (see Barbiers 1995). ${ }^{16}$

Then Wurmbrand (1999: 610) gives the following examples and states that in (23a) "John is in an obligation relation" and in (23b) "Mary is in a permission relation":
a. John must go to Alaska.
b. Mary can/may go to Alaska.

Having presented these examples, Wurmbrand continues by saying "The question, however, is, whether these relations (obligation, permission etc.) are theta-roles." Her main argument against such an analysis is to point out that in certain contexts "the modal forces do not have to be directed towards the subject", i.e. that deontic root modals like must and can/may sometimes have non-subject-oriented interpretations (or non-directed, as she calls them). They include the following (Wurmbrand (1999: 610):

(24) a. The traitor must die.

b. John must be home when the murder happens.

But the interpretation of non-subject-oriented root modals does not say much about the nature of the subject-oriented interpretations, except that it shows that there can be two variants of root readings for some verbs, subject-oriented and non-subject-oriented. We will return to this issue in the next section.

\section{Arguing against arguments against the control analysis of root modals}

In their work on modals, Wurmbrand (1999) and Eide (2005) argue against certain aspects of T\&V's analysis, especially their claim that certain modal constructions cannot have root readings and that this is because root modals assign a thematic role to their subject, like control verbs do, but epistemic modals are like regular raising verbs in not assigning a theta role to their subject. In the following I will consider the main points of this criticism in the light of the previous description of root and epistemic readings.

${ }^{16}$ As the reader will recall, Barbiers' term directed interpretation is also used by Eide (2005) in her classification of deontic (but not dynamic) readings, but subject-oriented interpretation is a more common term and it is used, for instance, by Barbiers \& van Dooren (2017) and adopted here. 


\subsection{The interpretation of modals with non-nominative subjects}

Although nominative is by far the most common subject case in Icelandic, many verbs take non-nominative subjects, as already mentioned (for an overview see Thráinsson 2007: $158 \mathrm{ff}$., with references). Because selection of this non-nominative subject case is determined by the main verb and not by the structural position of the NP (or DP), this case is often referred to as lexical (or inherent) case, as opposed to the structurally determined (or default) case, a distinction going back to Yip, Maling and Jackendoff (1987). ${ }^{17}$ As a consequence of this, lexical case is "preserved" in the derivation, e.g. in passives and raising constructions:

a. Stelpurnar hjálpuðu Haraldi.

girls-the helped Harold.DAT

'The girls helped Harold.'

b. Haraldi/*Haraldur var hjálpað (af stelpunum). Harold.DAT/*NOM was helped.SUP bygirls-the 'Harold was helped (by the girls).'

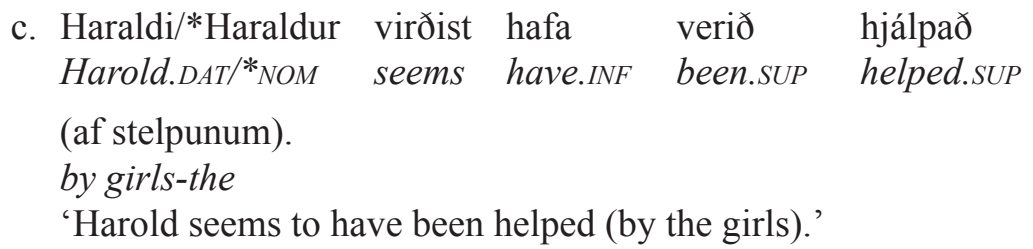

The verb hjálpa 'help' in (24a) assigns (lexical) dative to its object. In (24b) we see that this dative is preserved when the object has been "promoted" to the subject position in the passive. In (24c) a passive construction with help 'hjálpa' is embedded under the raising verb virðast 'seem' and the dative is still preserved on the subject and nominative is impossible.

Now if epistemic modals are like raising verbs in not assigning case nor thematic role to their subject and hence able to accept "raised" arguments

17 Similarly, the structural case of objects (in Icelandic) would be accusative whereas dative (and the rare genitive) case of objects would be lexical. Because some instances of nonaccusative object case are partly regular or predictable (see e.g. Barðdal 2001, Maling 2002), and the same is true of certain instances of non-nominative subjects (see e.g. Jónsson 2003; Eythórsson 2002), some linguists maintain that this distinction between lexical and structural case is misleading (see Barðdal 2011). That does not affect the arguments here. 
from the embedded infinitival complement, we would expect lexical case to be preserved in epistemic modal constructions. This is indeed the case (no pun intended), as pointed out by T\&V. Some of the examples that they use to demonstrate this were shown above and they are explained in more detail below:

(25) vanta 'lack, need' takes an accusative subject (dative for some speakers)
a. Mig vantar peninga.
me.ACC needs money.ACC
'I need money.'

b. Mig kann að vanta peninga.

me.ACC can to lack.INF money

'I may need money.'

[epistemic possibility only, subject-oriented root (ability) impossible]

c. Hana vill örugglega vanta peninga af og til. her.ACC will certainly need.INF money off and on 'She will certainly need (lack) money off and on.'

[epistemic probability (tendency) only, subject-oriented root (volition) impossible]

\section{(26) lika 'like' takes a dative subject}

a. Honum líkaði vel í Stuttgart.

him.DAT liked well in Stuttgart

'He was happy in Stuttgart.'

b. Honum atti að líka vel í Stuttgart. him.DAT ought.PST.SBJV to like.INF well in Stuttgart 'He should be happy in Stuttgart.' [epistemic probability only, subject-oriented root (obligation) impossible]

$\mathrm{T} \& \mathrm{~V}$ argue that the reason examples like the ones above cannot have a root reading follows from an analysis of root modals as control verbs that assign a thematic role to their subject. Hence there is no raising of arguments of 
the embedded infinitival complement to the subject position of the root modals, hence no "case preservation". The subject of the root modal is a thematic subject of the root modal and not a raised subject.

Wurmbrand has argued, on the other hand, that all modals are raising verbs (1999). Hence she has to come up with an explanation of facts like the Icelandic ones in (25)-(26). Her account goes like this:

we believe that this effect [i.e. that modal constructions like the ones in (25)-(26) only have an epistemic reading and not a root reading] is caused by the unnaturalness of a deontic interpretation in these examples. If the context is constructed in a way that favors a root/ deontic reading ... the examples are grammatical and again, only quirky case is possible for the subject (1999: 602)

Wurmbrand then gives the following examples to support her claim: ${ }^{18}$
a. Haraldi/*Haraldur
verður að líka
hamborgarar.
Harold.DAT/*NOM
must
to like.inf hamburgers
'Harold must like hamburgers'
his American in-laws)
(in order to be accepted by

b. Umsækjandann/*Umsækjandinn verður að vanta peninga. applicant-the.ACC/*NOM must to lack.INF money

'The applicant must lack money' (in order to apply for this grant)

I agree with the case marking given in Wurmbrand's examples and her idiomatic translations. Crucially, however, these root readings are nonsubject-oriented. As pointed out by a reviewer, they could be paraphrased roughly as 'It must hold that ...'. What they show, then, is that non-subjectoriented root readings may have certain properties of raising verbs, a fact overlooked by $\mathrm{T} \& \mathrm{~V}$ since they did not distinguish clearly between subject-oriented and non-subject-oriented root readings. In a "revised T\&V analysis" they could (i.e., we could!) maintain that subject-oriented root modals are like control verbs but non-subject-oriented root modals are like raising verbs.

$\overline{18}$ This argumentation and the examples are repeated by Barbiers \& van Dooren (2017: 6-7), but they mistakenly state (p. 6) that T\&V claim "that modals with a root interpretation systematically pattern with raising verbs". 
Now Wurmbrand (and Eide) could argue that if Icelandic subjectoriented root modals are like control verbs, then one would a priori expect that examples like the ones in (27) should be grammatical with nominative subjects and a subject-oriented root reading, but they are not. This is not a serious problem for the revised $\mathrm{T} \& \mathrm{~V}$ analysis though, since corresponding examples with regular control verbs such as reyna 'try' are also ungrammatical:
a. *Haraldur
reyndi að
líka
hamborgarar. Harold.NOM tried to
like.INF
hamburgers
b. *Umsækjandinn
reyndi
að vanta
peninga. applicant-the.NOM tried to lack.INF
money

But if control constructions with non-agentive complements are just semantically unnatural in some instances and not grammatically impossible (like the ones in (28) are), then the revised T\&V analysis of (Icelandic) subject-oriented root modals as control verbs and epistemic modals as raising verbs predicts that it should be possible to find passable pairs of examples of the type illustrated schematically in (29) where the modal V is the same in both constructions, the V.INF is also the same and the case of the non-nominative subject in (29b) is "inherited" from the infinitival complement:

(29) a. nom. subject - subject-oriented root modal V - V.INF that takes a non-nom. subject

b. non-nom. subject - epistemic modal V - V.INF that takes a non-nom. subject

While such pairs are not easy to come by, for reasons already described, the example in (30) is quite convincing. (Recall that vanta 'lack, need' takes an accusative subject; see the discussion around (8) above):
a. Ég vil ekk
vanta peninga. ${ }^{19}$
I.NOM want not lack.INF money
'I don't want to lack money.' [subject-oriented root, volition]

\footnotetext{
19 As a reviewer points out, some examples of this kind are more natural than others. Thus (30a) is probably more natural if the verb vilja is stressed and some context added: $\dot{E} g$ VIL ekki vanta peninga, en ég er samt alltaf blankur 'I don't WANT to lack money, but yet I'm broke all the time.'
} 
b. Mig vill örugglega ekki vanta peninga. me.ACC want definitely not lack money

'I won't tend to lack money.' [epistemic, probability (tendency)]

The additional pairs of this kind illustrated in (31)-(33) are modelled on examples in E. F. Sigurðsson (2012: 88) (recall that mistakast 'fail' and leiðast 'be bored' both take dative subjects):

a. ?Hann vill alls ekki mistakast. he.NOM wants byno means fail.INF

'He doesn't want to fail by any means.' [subject-oriented root, volition]

b. Honum vill örugglega mistakast af og til. him.DAT wants certainly fail.INF off and on 'He will certainly fail off and on.' [epistemic, probabilty (tendency)]

(32) a. ?Ég kann ekki að leiðast. I.NOM know not to be-bored.INF

'I don't know how to be bored.' [subject-oriented root, dynamic ability]

b. Mér kann að leiðast. me.DAT can to be bored.INF 'It is possible that I will be bored.' [epistemic, possibility]

a. ?Liðið æetlar að mistakast viljandi. team-the intends to fail.INF on purpose 'The team intends to fail on purpose.' [subject-oriented root, volition]

b. Liðinu æetlar greinilega að mistakast. team-the intends obviously to fail.INF 'It is obvious that the team will fail.' [epistemic, probability (tendency)] 
None of these example sentences are ambiguous - the ones with the nominative subject can only have the root reading indicated, the ones with the non-nominative subjects can only have the epistemic reading. Hence these sentences constitute counterarguments against a general raising analysis of modals, like the one proposed by Wurmbrand (1999), but the readings are as predicted under the revised $\mathrm{T} \& \mathrm{~V}$ analysis of subjectoriented root modals as control verbs and epistemic modals as raising verbs analysis, as explained above. ${ }^{20}$

\subsection{Non-argument subjects of root modal constructions}

A second type of arguments presented by Wurmbrand (1999) and Eide (2005) against the control analysis of (Icelandic) root modals advocated by T\&V has to do with non-argument subjects. Both Wurmbrand and Eide give examples of modal constructions with non-argument subjects that appear to be licensed by the infinitival complement but yet seem to have root readings. A couple of such examples were given above as $(17 \mathrm{a}, \mathrm{b})$, repeated here for convenience:

$$
\begin{aligned}
& \text { a. Баð verður að rigna í kvöld. } \\
& \text { it must to rain.INF to night } \\
& \text { 'It must (has to) rain tonight.' }
\end{aligned}
$$

[= otherwise we'll be in trouble]

b. Раð parf að rigna duglega.

it needs to rain.INF heavily

'It is necessary that it rains heavily.'

[= otherwise we'll be in trouble]

If the readings of these examples are root readings, it is clear that they are non-subject-oriented. Thus they do not constitute counterexamples agains the revised T\&V analysis. Examples like the ones in (35) would be more problematic if Eide is correct in maintaining (2005: 131) that they have a subject-oriented dynamic ability reading (Eide only talks about the Norwegian example, I have added the Icelandic variant of this idiom in (34b) and (35b)):

${ }^{20}$ E. F. Sigurðsson only gives examples corresponding to the nominative versions in (31)(33). The question marks are his, since he finds these examples less than perfect (and I agree), but he points out that they all have root readings. He uses this as arguments against Wurmbrand's claim that all modals are rasing verbs but he accepts her claim that some (non-subject-oriented) root modals should be analyzed as raising verbs. 
(34) a. Norwegian

Nød lærer naken kvinne å spinne.

need teaches naked woman to spin

b. Icelandic

Neyðin kennir naktri konu að spinna. need-the teaches naked woman to spin

'Need teaches a naked woman to spin.'

\section{(35) a. Norwegian}

Nød kan lære naken kvinne å spinne.

need can teach.INF naked woman to spin.INF

b. Icelandic

Neyðin getur kennt nakinni konu að spinna.

need-the can teach.SUP naked woman to spin.INF

'Need can teach a naked woman to spin.'

Contrary to Eide's analysis of the reading of the Norwegian examples as expressing subject-oriented ability, it seems to me that the meaning is more like a non-subject-oriented possibility reading: 'It is possible that ...' But maybe it is deontic rather than epistemic, as $T \& V$ would have classified it.

\section{Concluding remarks}

We have now "revisited" Icelandic modal verbs, mainly by reconsidering some aspects of T\&V's analysis of these. I argued that the main problem with T\&V's analysis was their failure to distinguish clearly between subject-oriented and non-subject-oriented root modals. Whereas they claimed that (Icelandic) root modals in general could be analyzed as control verbs, it has been shown in the literature that this does not hold for all root modals, assuming common definitions of "root". But if we take differences in subject orientation of modals into account, then it becomes clear that the arguments against T\&V's analysis of root modals only hold for the non-subject-oriented ones. Hence it may still be possible and profitable to analyze subject-oriented root modals as control verbs.

Having gone over various arguments against the control analysis of root modals, Barbiers \& van Dooren summarize the evidence as follows (2017: 8): 
In sum, it does not seem to be possible to account for the differences between epistemic and root interpretations in terms of theta-role assignment or argument structure. The evidence presented here suggests that modal auxilaries are raising verbs, which do not assign a theta-role to the surface subject. The question of whether the two types of root interpretations, namely subject-oriented and non-subject-oriented, can and should be distinguished syntactically is still open. If all modals are raising verbs and if in the subjectoriented interpretation the surface subject gets a theta-role from the modal, subject-oriented root interpretations pose a serious problem for the theta-criterion.

In the light of this, the main conclusions of the present paper could be summarized as follows:

- The evidence suggests that subject-oriented and non-subjectoriented root modals should be distinguished syntactically: The subject-oriented ones show properties of control verbs, the nonsubject-oriented ones could be raising verbs.

- Subject-oriented root modals arguably assign a theta-role to their subject. But since they are not raising verbs they do not pose a problem for the theta-criterion.

\section{References}

Barbiers, Sjef. 1995. The syntax of interpretation. Leiden: University of Leiden dissertation.

Barbiers, Sjef. 2002. Current issues in modality. An introduction to modality and its interaction with the verbal system. In Sjef Barbiers, Frits H. Beukema \& Wim van der Wurff (eds.), Modality and its interaction with the verbal system, 1-17. Amsterdam: John Benjamins.

Barbiers, Sjef, \& Annemarie van Dooren. 2017. Modal auxiliaries. In Martin Everaert \& Henk van Riemsdijk (eds.), The Wiley Blackwell companion to syntax, 2nd edn. Hoboken, NJ: John Wiley \& Sons. doi:10.1002/9781118358733. wbsyncom006.

Barðdal, Jóhanna. 2001. Case in Icelandic. A synchronic, diachronic and comparative approach. Lund: University of Lund dissertation.

Barðdal, Jóhanna. 2011. Lexical vs. structural case. A false dichotomy. Morphology 21(3-4). 619-654. doi:10.1007/s11525-010-9174-1. 
Brennan, Virginia M. 1993. Root and epistemic modal auxiliary verbs. Amherst, MA: University of Massachustetts dissertation.

Coates, Jennifer. 1983. The semantics of modal auxiliaries. London: Croom Helm. Davidsen-Nielsen, Niels. 1990. Tense and mood in English. A comparison with Danish. Berlin: Mouton de Gruyter.

Eide, Kristin Melum. 2005. Norwegian modals. Berlin: Mouton de Gruyter.

Eythórsson, Thórhallur. 2002. Changes in subject case marking in Icelandic. In David Lightfood (ed.), Syntactic effects of morphological change, 196-212. Oxford: Oxford University Press. doi:10.1093/acprof:oso/9780199250691.003.0011.

Jackendoff, Ray S. 1972. Semantic interpretation in generative grammar. Cambridge, MA: MIT Press.

Jónsson, Jóhannes Gísli. 2003. Not so quirky. On subject case in Icelandic. In Ellen Brandner \& Heike Zinsmeister (eds.), New perspectives in case theory, 127-163. Chicago: University of Chicago Press.

Maling, Joan. 2002. "Pað rignir págufalli á Íslandi." ['It rains datives in Iceland'] Verbs with dative objects in Icelandic. Íslenskt mál 24. 31-105.

Palmer, Frank R. 1986. Mood and modality. Cambridge: Cambridge University Press.

Rögnvaldsson, Eiríkur, Anton Karl Ingason, Einar Freyr Sigurðsson \& Joel Wallenberg. 2012. The Icelandic parsed historical corpus (IcePaHC). In Nicoletta Calzolari, Khalid Choukri, Thierry Declerck, Mehmet Uğur Doğan, Bente Maegaard, Joseph Mariani, Asuncion Moreno, Jan Odijk \& Stelios Piperidis (eds.), Proceedings of ELREC 2012, 1977-1984. Istanbul: European Language Resources Association.

Sigurðsson, Einar Freyr. 2012. Germynd en samt polmynd. Um nýju polmyndina $i$ islensku. ['Active but yet passive. On the New Passive in Icelandic']. Reykjavík: University of Iceland MA thesis.

Thráinsson, Höskuldur. 2007. The syntax of Icelandic. Cambridge: Cambridge University Press. doi:10.1017/CBO9780511619441.

Thráinsson, Höskuldur, \& Sten Vikner. 1995. Modals and double modals in the Scandinavian languages. Working Papers in Scandinavian Syntax 55. 51-88.

Wurmbrand, Susi. 1999. Modal verbs must be raising verbs. In Sonya Bird, Andrew Carnie, Jason D. Haugen \& Peter Norquest (eds.), WCCFL 18 Proceedings, 599-612. Somerville, MA: Cascadilla Press.

Yip, Moira, Joan Maling \& Ray Jackendoff. 1987. Case in tiers. Language 63. 217-250. doi:10.2307/415655. 